\title{
Impact of Former Iron Ore Mining on Soil Cover in the Northern Foreland of Poland's Świętokrzyskie Mountains
}

\author{
Monika Podgórska ${ }^{1 *}$, Marek Jóźwiak² \\ 'Institute of Biology, The Jan Kochanowski University, Uniwersytecka 7, 25-406 Kielce, Poland \\ ${ }^{2}$ Institute of Geography and Environmental Sciences, The Jan Kochanowski University, \\ Uniwersytecka 7, 25-406 Kielce, Poland
}

Received: 12 July 2019

Accepted: 8 September 2019

\begin{abstract}
The main objectives of this paper are to present the impact of former iron ore mining on the transformation of the soil cover and to demonstrate how these changes have affected plant cover. The research was carried out in 2012-2015 on the remnants of a former iron ore mining (gob piles) located in the northern foreland of the Świętokrzyskie Mountains. On two former post-mining fields eight soil profiles (four on the gob piles and four on untransformed areas) and eight phytosociological relevés were made using the Braun-Blanquet method. Physicochemical analyses were made of all the collected soil samples. The gob piles have favourable physico-chemical properties, differing from the properties of the poorer soils of the untransformed areas. Preferred chemical properties of the gob piles, including increased $\mathrm{pH}$ values and increased content of assimilated elements $(\mathrm{Ca}, \mathrm{Mg}, \mathrm{K}, \mathrm{Na})$ also affect the increase in the quality of fossil soil horizons. Former iron ore mining has led to significant, positive changes in the soil cover of the researched areas. The clayey-silty gob piles there have become fertile habitat islands among oligotrophic, sandy, untransformed soils, and the effect of these changes is an increase in the number of plant species.
\end{abstract}

Keywords: gob piles, soil profiles, vascular plant species, overburden, Poland

\section{Introduction}

Soils are a significant element of all ecosystems that are habitats for specific plant and animal species [1-5]. The specificity of soils, their diversity, as well as long-term formation process leads to significant soilplant relations $[6,7]$. Unfortunately, these relations are

*e-mail: iris@ujk.edu.pl often uncompromisingly destroyed as a result of many anthropogenic factors [8,9]. The widest-ranging factors are progressive urbanization and industrialization, including so-called industrial agriculture [10-13].

One of the main global economic sectors putting significant pressure on natural ecosystems is the mining industry [14-16]. Opencast mining is the most common approach, and this results in destruction of the natural environment at all levels. This often irreversible process affects entire biocoenoses, together with their habitats, rocky layers, and parent rocks providing the basis 
for formation of the soil cover. In many cases, the regeneration of natural ecosystems is impeded or even made impossible due to the specificity of the substrate in post-mining areas $[17,18]$, including but not limited to the area of the spoil heaps. These are areas of waste material that are deprived of soil cover, contain only a small amount of nutrients, and are heavily drained. This makes them unfavourable to the development of most plants, especially more demanding ones (such as forest species requiring level-diversified plant communities and specific soil horizons, for example humus). As a result, the regeneration of ecosystems in post-mining areas must be supported by reclamation processes [19, 20]. These sites also often become habitats for invasive anthropophytes [21, 22]. All these processes lead to a drastic decline in the biodiversity of a given area [23-26].

But there are also events of mining activity which have a completely different effect on the natural environment: former mining activity [27]. This was the main type of mining from around the $15^{\text {th }}$ century to the beginning of the $20^{\text {th }}$ century in the area of southern Poland. In comparison with modern methods, iron ore mines were not very invasive, which led to their excavated, post-mining remnants, commonly known as gob piles, having a very specific character. Gob piles are small heaps of unprocessed material extracted from deeper rock layers and piled up around the heads of old shafts [28]. In this way, the gob piles differ from typical heaps of post-mining waste [29-32].

The remnants of iron-ore mining sites are habitats where mesophilous deciduous forest communities developed [33], and show significantly higher species richness [34]. However, modern forest management techniques in their area can lead to a secondary decline in their floristic diversity [35]. It is also worth noting that these communities are reservoirs for ancient woodland plant species [36].

These sites are unique on the European scale because of the genesis of the gob piles, the specific habitat conditions of the heaps, and the unusual character of the communities formed there. An analysis of the material collected by the authors so far has led them to present the following research hypothesis: former iron ore mining sites have created positive changes in the soil cover in the northern foreland of the Swiętokrzyskie Mountains.

The main objectives of this paper are to present the impact of former iron ore mining on the transformation of the soil cover in the researched area, and to demonstrate how the changes found in the substrate have affected the plant cover there.

\section{Material and Methods}

\section{Study Area}

The research was conducted on the remnants of a former iron ore mining in the area of Suchedniów
Plateau and Gielniów Hummock. These two regions are located in the northern Mesozoic fringe of the Palaeozoic core of the Świętokrzyskie Mountains (southern Poland).

The area of the Suchedniów Plateau occupies wide, flat and domed elevations (270-441 m a.s.1.), formed of Triassic sandstones and clays, while the hills of Gielniów Hummock (208-408 m a.s.1.) consist of an alternating series of Jurassic sandstones. Acidic podzolic soils created on a quartz-silicate series dominate in both regions, which is why fertile habitats occur only sporadically and are limited mainly to sites with natural outcrops of the marly-silicate series. The area of Suchedniów Plateau is composed of Triassic sandstones and clays, while Gielniów Hummock consists of an alternating series of Jurassic sandstones. Ore-bearing horizons made of clays and ore-bearing shale clays containing clay siderite and spherosiderites were present in both the Triassic formations (mainly in the Lower Triassic), and in the Jurassic formations (Lower Jurassic), and had been the subject of mining [37].

The landscape of this area is dominated by natural vegetation, with a majority of acidic beech communities (Luzulo-Fagetum) and pine forests (Leucobryo-Pinetum, Molinio-Pinetum and Calamagrostio villosae-Pinetum). In addition, there are also multi-species mixed forests with a large percentage of Abies alba and Fagus sylvatica, with Acer pseudoplatanus and Larix decidua s.l.) [38].

The most intensive iron ore mining occurred in the northern foreland of the Świętokrzyskie Mountains [27]. The first mines there date back to the $12^{\text {th }}-15^{\text {th }}$ centuries, with ore mining flourishing in the $17^{\text {th }}$ century following development of the blast furnace. The last mines ceased operation there in the middle of the $20^{\text {th }}$ century [39]. The mining fields were established in dense forest complexes, and the iron ore was mined by hand using a deep-shaft method. The ore was picked out from the material excavated to the surface, and the unnecessary material was left piled around the shaft heads [37]. As a result, these remnants (gob piles), are now scattered throughout the forest communities of the entire northern foreland of the Świętokrzyskie Mountains. They look like small heaps of earth, from 1-3 $\mathrm{m}$ in height, dug-up and left behind by the miners from the mine shaft in the middle of the heap [28, 34].

Our research covered the two selected iron ore mining fields (first - 51 $06^{\prime} 06^{\prime \prime} \mathrm{N}, 20^{\circ} 29^{\prime} 22^{\prime \prime} \mathrm{E}-$ on the

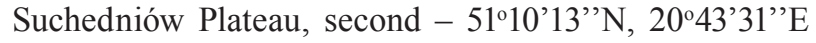
- on the Gielniów Hummock), which were active from the $18^{\text {th }}$ to the $19^{\text {th }}$ centuries. Each of the fields consists of gob piles and untransformed land surrounding the individual heaps. In the $1950 \mathrm{~s}$, two tree species were introduced to the forest stands on both post-mining fields: Pinus sylvestris (across almost all of the first mining field), and both Fagus sylvatica and Pinus sylvestris (across almost all of the second mining field). The trees were planted both on gob piles as well as on 
untransformed land within the post-mining fields. Data Set

The research was carried out in 2012-2015. Eight soil profiles were made in the area of the fields. Four were made of the gob piles (with two for each field). For comparison, the other four were made of untransformed areas (also two for each field) at a distance of $5 \mathrm{~m}$ from the boundary of each heap. Soil samples were taken from each soil horizon for analysis.

In addition, in close proximity to each soil pit (on the gob piles and in their surroundings), 8 phytosociological relevés were made using the Braun-Blanquet method [40] to determine the floristic composition of the plant communities growing there. Each relevé covered an area of $100 \mathrm{~m}^{2}$.

\section{Data Analysis}

Physicochemical analyses were made of all the collected soil samples using methods generally accepted in the field of soil science. The following variables were determined: the $\mathrm{pH} \mathrm{H}_{2} \mathrm{O}$ of soil suspension in distilled water (potentiometric method); carbonates, using the Scheibler method; the total exchangeable alkalis using the Kappen method; exchangeable acidity using the Sokołów method; hydrolytic acidity with the Kappen method; $\mathrm{Ca}, \mathrm{K}, \mathrm{Na}, \mathrm{Mg}$ availability content, and granulometric composition using the Casagrande sedimentation method, as modified by Prószyński. Additionally, humus content was determined using the Tiurin method for the samples collected from the top levels of the gob piles and the untransformed areas (these levels have a direct impact on plant cover).

In terms of the selected variables, the differences between the analyzed gob piles and the untransformed areas were determined using the Mann-Whitney U test $(P \leq 0.05)$. The following variables were taken into account: chemical soil properties $(\mathrm{pH}$, carbonate content, available $\mathrm{Ca}, \mathrm{K}, \mathrm{Na} \mathrm{Mg}$ content, humus content); physical soil properties (content of clayey particles); total number of vascular plant species; number of species characteristic of Querco-Fagetea and Vaccinio-Piceetea class, and the number of ecological indicator values of vascular plants (i.e., the acidity value) [41]. Correlations were made to demonstrate the relationship between the individual chemical and physical properties of the top layers of the soils $(\mathrm{pH}$, $\mathrm{Ca}, \mathrm{K}, \mathrm{Na} \mathrm{Mg}$ content, total exchangeable alkalis, exchangeable acidity, hydrolytic acidity, clayey particles), and the number of identified groups of species. The correlation strength was measured using the Spearman correlation coefficient $(r)$.

The nomenclature of soil horizons and soil layers was used according to Kowalkowski et al. [42], the nomenclature of species according to Mirek et al. [43], and syntaxon names according to Matuszkiewicz [44]. The analyses were carried out using Statistica 6.1 $[45]$.
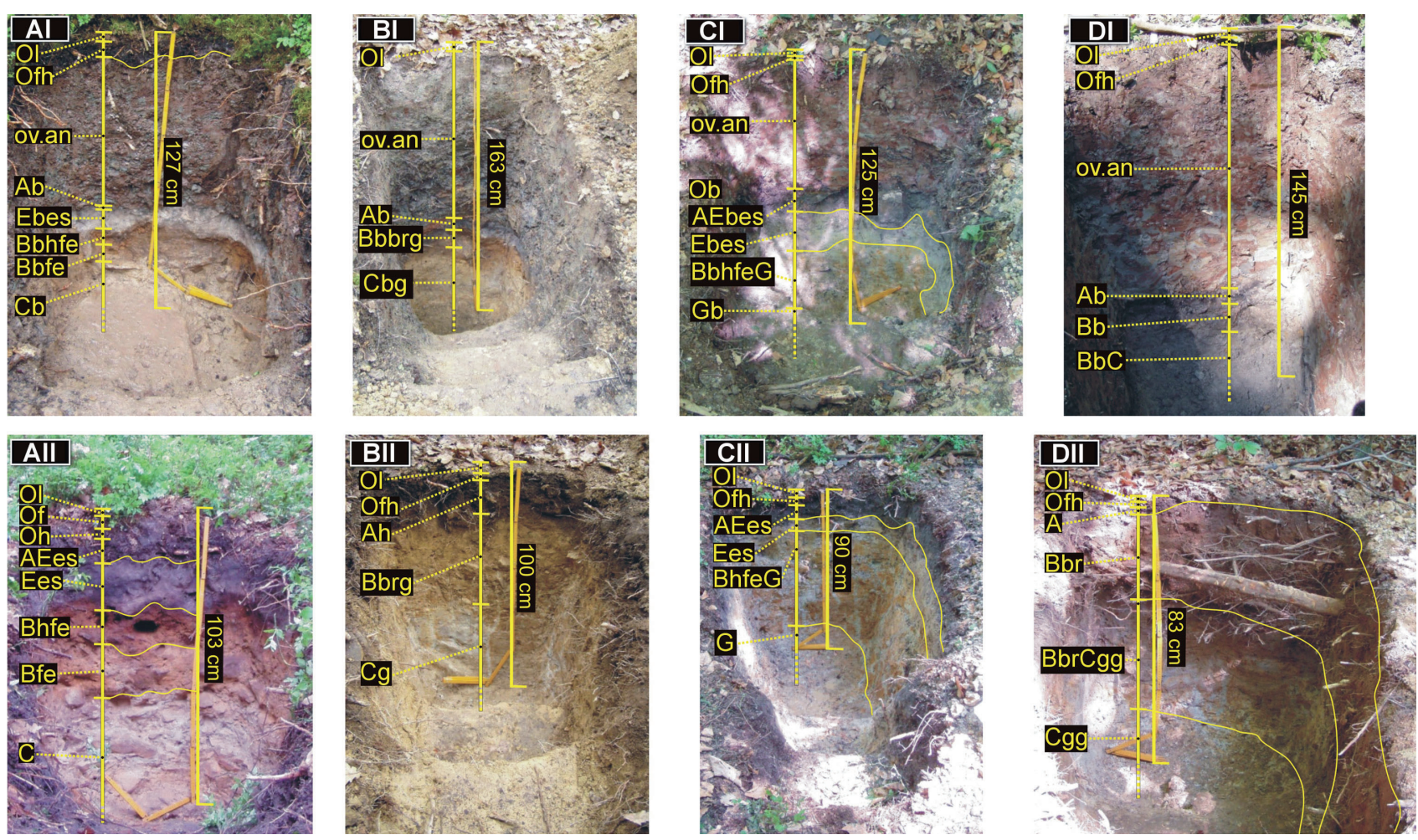

Fig. 1. Soil profiles of the gob piles (AI-DI) and in their surroundings (AII-DII); ov.an - overburden. 


\section{Results and Discussion}

\section{Characteristics of Soil Profiles within Gob Piles and Their Surroundings}

\section{First Post-Mining Field}

Soil pit No. 1 was made in a gob pile (Fig. 1, AI), from which 5 soil horizons were distinguished. The 9 $\mathrm{cm}$ thick organic horizon $(\mathrm{O})$ contained two $\mathrm{Ol}$ and Ofh sub-horizons. A moder humus type was distinguished. The next horizon was a $62 \mathrm{~cm}$ thick overburden, created as a result of the mining activity, and consisted of compact, clayey-silty material. Fossil soil was found underneath in a clearly developed, $1 \mathrm{~cm}$-thick humus horizon (Ab), a $7 \mathrm{~cm}$-thick light-grey eluvial horizon (Ebes), and an $18 \mathrm{~cm}$-thick accumulation horizon (Bb), at which point two Bbhfe and Bbfe sub-horizons were distinguished. The parent rock $(\mathrm{Cb})$ horizon was found at a depth of $97 \mathrm{~cm}$. The depth of the entire soil pit was $127 \mathrm{~cm}$.

The presence of 6 soil horizons was found in the profile taken from soil pit No. 2 (Fig. 1, AII) made in an untransformed area $3 \mathrm{~m}$ from soil pit No. 1. These were: a $9 \mathrm{~cm}$-thick organic horizon $(\mathrm{O})$ with three subhorizons (Ol, Of, Oh - mor humus); an $8 \mathrm{~cm}$ dark-grey transitional horizon (AEes); and a $13 \mathrm{~cm}$-thick eluvial horizon (Ees). Two Bhfe and Bfe sub-horizons were distinguished in the $33 \mathrm{~cm}$ thick accumulation horizon (B). The parent rock (C) started at a depth of $63 \mathrm{~cm}$. The depth of the entire soil pit was $103 \mathrm{~cm}$.

Both of the profiles were made in the part of the first mining field, where Pinus sylvestris dominated the forest stand.

In the second part of first post-mining field, with less share of the Pinus sylvestris in the forest stand, two other soil pits were also made. Soil pit No. 3 (Fig. 1, BI) was made on the slopes of a gob pile. In a $5 \mathrm{~cm}$-thick organic horizon $(\mathrm{O})$ only $\mathrm{Ol}$ sub-horizon was distinguished, consisting mainly of fallout from deciduous trees. Under the organic horizon, a $98 \mathrm{~cm}$ thick overburden was found, which consisted of a dark grey material with reddish-brown iron, containing strands compounds. It also contained fragments of preserved silty siderites. In the upper part, at a depth of 6-7 cm, the overburden was fragmented. Fossil soil was present at a depth of $98 \mathrm{~cm}$ under the overburden with a clearly developed $8 \mathrm{~cm}$ thick, dark-grey fossil humus horizon (Ab). A $12 \mathrm{~cm}$-thick accumulated fossil horizon was present at a depth of $106 \mathrm{~cm}$, which exhibited the properties of a reddish-brown gley (Bbbrg). Light-coloured parent rock with a marked gleysol top (Cbg horizon) began at $118 \mathrm{~cm}$. The depth of the entire soil pit was $163 \mathrm{~cm}$.

At a distance of $3 \mathrm{~m}$ from the gob pile, in an area not covered by overburden, soil pit No. 4 was made (Fig. 1, BII). In this soil pit, the organic horizon had a thickness of $5 \mathrm{~cm}$. A $2 \mathrm{~cm}$-thick detritus sub-horizon Ofh (moder humus) was present under a $3 \mathrm{~cm}$-thick fresh forest litter sub-horizon (Ol). Underneath this, at a depth of 5-17 cm, a humus horizon (Ah) was found with marked quantities of organic matter. At a depth of 17-60 cm, a $43 \mathrm{~cm}$-thick accumulated horizon with visible light brown gley (Bbrg) was found. The lightcoloured parent rock (Cg horizon), with a markedly gley top (whitish bleeds visible), began at a depth of $60 \mathrm{~cm}$. The entire soil pit had a depth of $100 \mathrm{~cm}$.

\section{Second Post-Mining Field}

Soil pit No. 5 (Fig. 1, CI) was made in a complex of shallow gob piles. In this soil pit, the $3 \mathrm{~cm}$ organic horizon consisted of a $2 \mathrm{~cm}$ fresh forest litter sub-horizon $(\mathrm{Ol})$, composed of fallout from deciduous trees and Pinus sylvestris needles, as well as the $1 \mathrm{~cm}$ detritus sub-horizon (Ofh) (moder humus). At a depth of 3-60 cm, a compact, reddish-grey overburden was found. At a depth of 3-10 cm, the overburden was mostly fragmented. Beneath the overburden was fossil soil with a thin organic horizon (Ob); an $8 \mathrm{~cm}$-thick dark-grey fossil horizon (AEbes); a $21 \mathrm{~cm}$-thick eluvial horizon (Ebes); an accumulation horizon $(\mathrm{Bb})$ with a noticeable eluvial accumulation of iron; and a gley horizon (BbhfeG). A steel-grey gley horizon with spotted colouration $(\mathrm{Gb})$ then began at a depth of $118 \mathrm{~cm}$. The depth of the entire soil pit was $125 \mathrm{~cm}$.

Soil pit No. 6 (Fig. 1, CII) was made on untransformed ground $5 \mathrm{~m}$ from the gob pile used for soil pit No. 5. The presence of a $6 \mathrm{~cm}$-thick organic horizon $(\mathrm{O})$ with $\mathrm{Ol}$ sub-horizon was found in this profile, which consisted mainly of pine needles and Ofh sub-horizon (moder humus). At a depth of $6 \mathrm{~cm}$, a $7 \mathrm{~cm}$-thick, dark-grey, compact AEes horizon was found. A $6 \mathrm{~cm}$-thick lightish-grey eluvial horizon (Ees) was then seen at a depth of $13 \mathrm{~cm}$. The transition between the AEes and Ees horizons was clearly wavy. At a depth of $19-75 \mathrm{~cm}$, the accumulation horizon was found with a noticeable eluvial accumulation of iron and a marked gley horizon (BhfeG), which transitioned into a barely visible gley horizon $(\mathrm{G})$ at a depth of $75 \mathrm{~cm}$. The depth of the entire soil pit was $90 \mathrm{~cm}$.

Soil pit No. 7 (Fig. 1, DI) was made in the slopes of a high gob pile within the same field. In this pit, the organic horizon $(\mathrm{O})$ consisted of a $3 \mathrm{~cm}$-thick fresh forest litter sub-horizon $\mathrm{Ol}$ (this was mainly composed of Fagus sylvatica leaves) and a dark grey detritus sub-horizon (Ofh) at a depth of 3-5 cm (moder humus). At a depth of $5 \mathrm{~cm}$, an overburden began which reached a depth of $95 \mathrm{~cm}$. Beneath the overburden was a fossil soil in which an $8 \mathrm{~cm}$ humus horizon $(\mathrm{Ab})$ was found, with a $17 \mathrm{~cm}$ accumulation horizon $(\mathrm{Bb})$ and a quartzite-bearing transition horizon $(\mathrm{BbC})$. The depth of the entire soil pit was $145 \mathrm{~cm}$.

At a distance of $5 \mathrm{~m}$ from the gob pile with soil pit No. 7, an eight soil pit was made in an untransformed area (soil pit No. 8 - Fig. 1, DII). In this pit, a $4 \mathrm{~cm}$ thick organic horizon $(\mathrm{O})$ was found, where a fresh 
forest litter sub-horizon (Ol), distinguished mostly of Fagus sylvatica leaves, and a detritus sub-horizon (Ofh) of moder humus. Below the organic horizon, a thin humus horizon (A) was found, with a thickness of $3 \mathrm{~cm}$ and a compact, reddish-brown accumulation horizon (Bbr) present beneath it. At a depth of $32-75 \mathrm{~cm}$ there was a $43 \mathrm{~cm}$-thick transition horizon (BbrCgg). This horizon was compacted and characterized by very small rooting. A compact parent rock horizon (Cgg) with a strong bottom gley started from $75 \mathrm{~cm}$. The depth of the entire soil pit was $83 \mathrm{~cm}$.

\section{Positive Changes in the Soil Cover Caused by Mining}

In both post-mining fields, significant differences were found in the physical and chemical properties of the substrate between the gob piles and their surroundings (untransformed areas).

In the case of the gob piles, the overburden excavated by the miners is a direct habitat for plants, while for the untransformed area it is the humus horizon (A horizon). Overburden $\mathrm{pH}$ measured within the soil pits made in the gob piles range from 5.3 to 7.0 (average 6.1). In contrast, the $\mathrm{pH}$ of the humus horizon (A) of the surroundings ranged from 4.3 to 4.9 (average 4.6). The difference in $\mathrm{pH}$ between the overburden and the humus horizon of the untransformed area is significant $(P=0.021, U=2.31)$. The $\mathrm{pH}$ values of the overburden ranged from acidic to neutral. In comparison, the $\mathrm{pH}$ of the untransformed soils was strongly acidic (Table 1). Significant differences between the overburden of the gob piles and horizon $\mathrm{A}$ of the untransformed areas were also found in the presence of available contents of $\mathrm{Ca}, \mathrm{K}, \mathrm{Mg}$ and $\mathrm{Na}$ (Table 1). The greatest difference was found in calcium content: in the overburden calcium content ranged from $117.8 \mathrm{mg} / 100 \mathrm{~g}$ to $167.3 \mathrm{mg} / 100 \mathrm{~g}$ (average $144.44 \mathrm{mg} / 100 \mathrm{~g}$ ), and in the humus horizon of the untransformed areas, from $8.3 \mathrm{mg} / 100 \mathrm{~g}$ to $24.1 \mathrm{mg} / 100 \mathrm{~g}$ (average $15.9 \mathrm{mg} / 100 \mathrm{~g}$ ) (Table 1).

The overburden, which is a direct substrate for the plants on the gob piles, is characterized by lower humus content (from $1.03 \%$ to $1.62 \%$, average $1.37 \%$ ), compared to horizon A of the untransformed areas (from $2.52 \%$ to $4.86 \%$, average $3.72 \%)(P=0.02$; $U=-2.32)$, as well as lower values of exchange acidity and hydrolytic acidity (Table 1).

In addition to the differences in the chemical properties of both areas (the overburden on the gob piles and the humus horizon on the untransformed areas), there are also significant differences in their granulometric composition. The overburden is characterized by a high percentage of loamy parts (from 51.8 to $82.7 \%$, averaging $70.2 \%$ ), resulting in its clayey particles constituting average $70.6 \%$ of its content. The humus horizon of the untransformed areas is characterized by a high percentage of sandy parts (from $62.3 \%$ to $90.3 \%$, averaging $75.9 \%$ ), which results in average clayey particles content of only $11.6 \%$. The difference in clayey particle content is statistically significant at $P=0.02(U=2.31)$ (Table 1). Thus, the researched granulometric composition of the overburden indicates that we are dealing with clayey loam, while the humus horizon is mainly represented by clayey sand.

In comparison to the humus horizon of the untransformed areas, the anthropogenic overburden's

Table 1. Differences between chemical and physical characteristics of overburden of gob piles and A horizon of non-transformed areas two horizons which are the main habitats for plants; $* 0.05 \geq \mathrm{P} \geq 0.01$.

\begin{tabular}{|c|c|c|c|c|c|c|}
\hline \multirow{2}{*}{\multicolumn{2}{|c|}{ Characteristics }} & \multirow{3}{*}{$\begin{array}{c}\text { Units } \\
\text { (pH unit) }\end{array}$} & \multicolumn{2}{|c|}{ Range } & \multicolumn{2}{|c|}{ Mean values } \\
\hline & & & \multirow{2}{*}{$\begin{array}{c}\text { Overburden } \\
5.3-7.0\end{array}$} & \multirow{2}{*}{$\frac{\text { A horizon }}{4.3-4.9}$} & \multirow{2}{*}{$\begin{array}{c}\text { Overburden } \\
6.1^{*}\end{array}$} & \multirow{2}{*}{$\begin{array}{c}\text { A horizon } \\
4.6\end{array}$} \\
\hline \multirow{10}{*}{ Chemical } & $\mathrm{pH}_{\mathrm{H} 20}$ & & & & & \\
\hline & carbonates & $(\%)$ & $0.2-0.2$ & $0.17-0.2$ & 0.2 & 0.2 \\
\hline & $\mathrm{Ca}$ & $(\mathrm{mg} / 100 \mathrm{~g})$ & $117.8-167.3$ & $8.3-24.1$ & $144.4^{*}$ & 15.9 \\
\hline & $\mathrm{K}$ & $(\mathrm{mg} / 100 \mathrm{~g})$ & $13.6-23.6$ & $2.8-5.7$ & $18.4^{*}$ & 4 \\
\hline & $\mathrm{Na}$ & $(\mathrm{mg} / 100 \mathrm{~g})$ & $1.2-1.7$ & $0.5-0.9$ & $1.4 *$ & 0.7 \\
\hline & $\mathrm{Mg}$ & $(\mathrm{mg} / 100 \mathrm{~g})$ & $51.0-79.0$ & $0.3-0.9$ & $61.9 *$ & 0.5 \\
\hline & Total exchangeable alkalis & $(\mathrm{me} / 100 \mathrm{~g})$ & $7.5-14.9$ & $0.3-2.9$ & $11.9^{*}$ & 1.5 \\
\hline & Exchangeable acidity & $(\mathrm{me} / 100 \mathrm{~g})$ & $6.7-9.8$ & $6.2-16.1$ & 8.1 & 11.7 \\
\hline & Hydrolytic acidity & $(\mathrm{mmol} / 100 \mathrm{~g})$ & $1.2-3.2$ & $6.6-11.3$ & $2.4 *$ & 8.5 \\
\hline & Humus content & $(\%)$ & $1.03-1.62$ & $2.52-4.86$ & $1.37 *$ & 3.72 \\
\hline \multirow{3}{*}{ Physical } & Sandy parts & $(\%)$ & $1.0-35.0$ & $62.3-90.3$ & $15^{*}$ & 75.9 \\
\hline & Loamy parts & $(\%)$ & $51.8-82.7$ & $9.7-34.0$ & $70.6^{*}$ & 22.5 \\
\hline & Clayey particles & $(\%)$ & $52.5-88.2$ & $3.0-22.8$ & $70.2 *$ & 11.6 \\
\hline
\end{tabular}




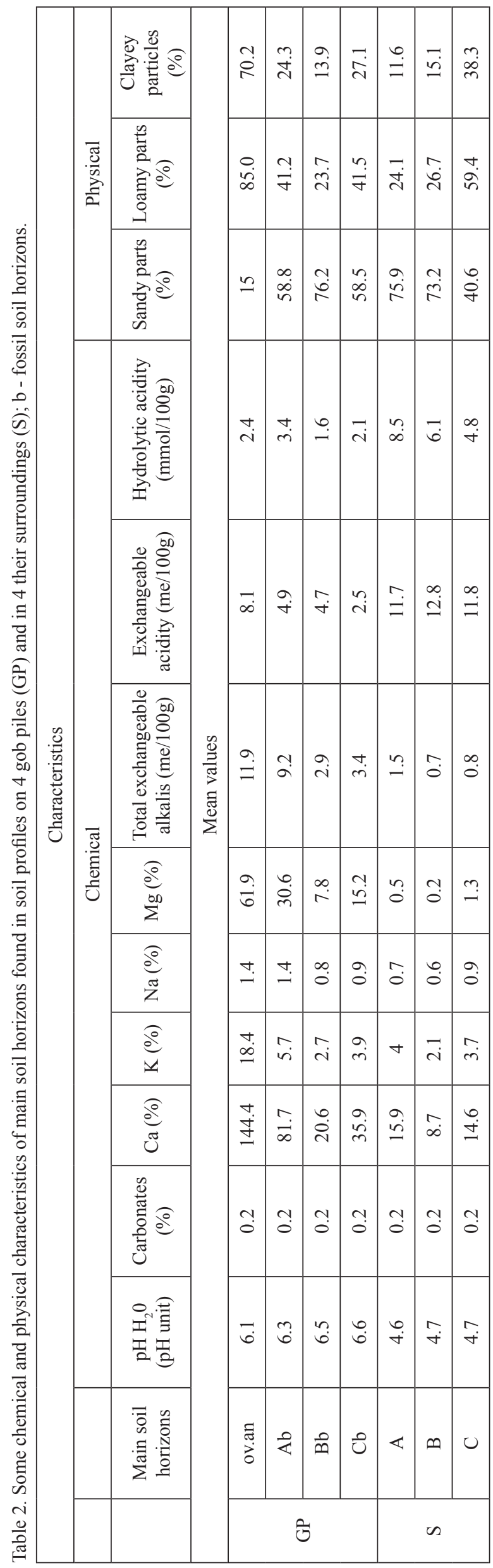

different chemical and physical properties also influenced the change in the chemical properties of the fossil soil horizon beneath it (Table 2). Primarily, the overburden caused an increase in the $\mathrm{pH}$ value of the fossil horizon, an increase in the content of researched elements $(\mathrm{Ca}$ and $\mathrm{Mg}$ in particular), and increased values of total exchangeable alkalis compared to the untransformed soil horizons (Table 2).

As a result of the mining works carried out in the researched area, the originally acidic sandy soil deposits were covered with unprocessed material extracted from deeper rock layers (Fig. 1, AI-DI). The research showed that the overburden has a number of chemical and physical properties (including increased $\mathrm{pH}$, or $\mathrm{Ca}$, $\mathrm{K}, \mathrm{Na}, \mathrm{Mg}$ content - Tables 1 and 2), which help create habitats for more demanding plant species. The material forming the gob piles originated from the ore horizon (from the marly-silicate series), which contains marls. This can affect an increase in $\mathrm{pH}$ compared to the surroundings of the untransformed areas with poor and acidic soils formed from the quartz-silicate series [46].

Additionally, in the areas of the former iron ore mining, the excavated overburden could become a new 'parent rock' for the soils formed upon it. Creation of the first 'new soil' horizons on the overburden, being an advantageous soil-forming substrate, was first observed on the gob piles in one of the oldest post-mining fields (formed before the $15^{\text {th }}$ century) by Adamczyk [47]. In contrast, on the oldest gob piles in the currently researched area - soil pit No. 5 (Fig. 1, CI), strong fragmentation of the overburden was observed in its upper part, which suggests the beginning of the formation of the next soil horizon under the organic horizon.

The physical and chemical properties of fossil soils are mainly related to their parent rock $[48,49]$. In the case of the researched gob piles, significant differences between the chemical properties of the fossil soils and the untransformed soils were found, despite the fact that they developed in close proximity to each other, on the same parent rock, and have the same soil horizons (Fig. 1). Changes in the chemical properties of these fossil soils are clearly influenced by the overburden, leading to increased $\mathrm{pH}$ value and the amounts of certain elements (mainly $\mathrm{Ca}$ and $\mathrm{Mg}$ ), in comparison the soils which are not covered with overburden (Table 2). This phenomenon is unusual because of the specific, advantageous properties of the overburden (Table 1). In other post-mining areas, the phenomenon of fossil soils being enriched by their overburden's properties does not occur, because this is most often a highly processed material of poorer quality than the fossil soils it is covering [50, 51].

\section{The Positive Effect of Former ore Mining Activities on Plant Cover}

Gob piles formed of overburden excavated during mining activities are a more fertile habitat for 
plants, compared to habitats in untransformed areas. Phytosociological relevés of the gob piles show a higher number of plant species (60 species) compared to the number of species growing in areas not transformed by mining (21 species) $(P=0.02, U=2.32)$. In individual phytosociological relevés of the heaps, the number of species ranges from 19 to 39, while in untransformed areas these numbers are just 5 to 12 species (Table 3 ).

When analysing the percentage of species in both types of habitats, based on acidity values it was found that there was a significant increase in the number of alkaline species (15) in the former iron ore mining

Table 3. A synoptic table of floristic composition of communities developed on gob piles (GP) and in their surroundings (S) in two mining fields.

$\mathrm{I}-\mathrm{V}$ - constancy: $\mathrm{II}=21-40 \%, \mathrm{III}=41-60 \%, \mathrm{IV}=61-80 \%, \mathrm{~V}=81-100 \% ;+-5-$ abundance: $+<5 \%, 1=5 \%, 2=5-25 \%, 3=25-50 \%$, $4=50-75 \%, 5=75-100 \%$ (Braun-Blanquet 1964); R - acidity value: alk: alkaline species, neut: neutrophyte, acid: moderately acidophyte, acid+: strong acidophyte, acid-: light acidophyte (Zarzycki et al. 2002).

\begin{tabular}{|c|c|c|c|c|}
\hline Type of habitat & & & GP & $\mathrm{S}$ \\
\hline Average cover of tree layer & $\mathrm{a}[\%]$ & & 56 & 46 \\
\hline Average cover of shrub layer & $\mathrm{b}[\%]$ & & 32 & 22 \\
\hline Average cover of herb layer & $\mathrm{c}[\%]$ & & 70 & 40 \\
\hline Average cover of moss layer & $\mathrm{d}[\%]$ & & 1 & 0 \\
\hline Average number of species & & & 27 & 9 \\
\hline Number of relevés in table & & & 4 & 4 \\
\hline Characteristics & Layer & $\mathrm{R}$ & Constancy and abundance & Constancy and abundance \\
\hline $\begin{array}{c}\text { Trees and shrubs: } \\
\text { ChCl. Querco-Fagetea }\end{array}$ & & & & \\
\hline Fagus sylvatica (planted) & $\mathrm{a}, \mathrm{b}, \mathrm{c}$ & alk & $\mathrm{III}^{2-4}$ & $\mathrm{III}^{+-2}$ \\
\hline Carpinus betulus & $\mathrm{a}, \mathrm{b}, \mathrm{c}$ & neut & $\mathrm{IV}^{+-3}$ & $\mathrm{II}^{+-2}$ \\
\hline Corylus avellana & $\mathrm{b}$ & neut & $\mathrm{III}^{+-2}$ & $\mathrm{II}^{+}$ \\
\hline Cerasus avium & $\mathrm{b}, \mathrm{c}$ & neut & $\mathrm{II}^{+-1}$ & . \\
\hline Daphne mezereum & $\mathrm{b}, \mathrm{c}$ & alk & $\mathrm{II}^{+}$ & . \\
\hline $\begin{array}{c}\text { Padus avium } \\
\mathrm{ChCl} \text {. Vaccinio-Piceetea }\end{array}$ & $\mathrm{b}$ & alk & $\mathrm{II}^{+}$ & . \\
\hline Pinus sylvestris (planted) & $\mathrm{a}$ & acid & $\mathrm{III}^{2-3}$ & $\mathrm{IV}^{3}$ \\
\hline Abies alba & $\mathrm{a}, \mathrm{b}, \mathrm{c}$ & acid $^{-}$ & $\mathrm{III}^{+-2}$ & $\mathrm{III}^{+-2}$ \\
\hline $\begin{array}{c}\text { Picea abies } \\
\text { Others: }\end{array}$ & $\mathrm{a}, \mathrm{b}, \mathrm{c}$ & acid + & $\mathrm{IV}^{+}$ & $\mathrm{III}^{+-3}$ \\
\hline Quercus robur & $\mathrm{a}, \mathrm{b}, \mathrm{c}$ & neut & $\mathrm{III}^{+-3}$ & $\mathrm{III}^{+-2}$ \\
\hline Quercus petraea & $\mathrm{a}, \mathrm{b}, \mathrm{c}$ & neut & $\mathrm{II}^{+}$ & $\mathrm{III}^{+-2}$ \\
\hline Populus tremula & $\mathrm{a}, \mathrm{b}, \mathrm{c}$ & acid $^{-}$ & $\mathrm{III}^{+-3}$ & $\cdot$ \\
\hline Larix decidua & $\mathrm{a}$ & acid $^{-}$ & $\mathrm{III}^{+-3}$ & $\mathrm{III}^{+-2}$ \\
\hline Betula pendula & $\mathrm{a}, \mathrm{c}$ & neut & $\mathrm{II}^{+}$ & . \\
\hline Pyrus communis & $\mathrm{b}$ & alk & $\mathrm{II}^{+-2}$ & $\cdot$ \\
\hline Rubus hirtus & $\mathrm{b}, \mathrm{c}$ & neut & $\mathrm{V}^{+-3}$ & $\mathrm{IV}^{+-3}$ \\
\hline Frangula alnus & $\mathrm{b}, \mathrm{c}$ & acid $^{-}$ & $\mathrm{III}^{+-2}$ & $\mathrm{IV}^{+-1}$ \\
\hline Sorbus aucuparia & $\mathrm{b}, \mathrm{c}$ & acid $^{-}$ & $\mathrm{IV}^{+}$ & $\mathrm{II}^{+-1}$ \\
\hline Viburnum opulus & $\mathrm{b}, \mathrm{c}$ & neut & $\mathrm{IV}^{+-1}$ & . \\
\hline Prunus spinosa & $\mathrm{b}$ & alk & $\mathrm{III}^{+-2}$ & . \\
\hline Rhamnus cathartica & $\mathrm{b}$ & alk & $\mathrm{II}^{+}$ & . \\
\hline
\end{tabular}


Table 3. Continued.

\begin{tabular}{|c|c|c|c|c|}
\hline Type of habitat & & & GP & $\mathrm{S}$ \\
\hline Characteristics & Layer & $\mathrm{R}$ & Constancy and abundance & Constancy and abundance \\
\hline \multicolumn{5}{|l|}{ Forest floor vegetation: } \\
\hline \multicolumn{5}{|l|}{ ChCl. Querco-Fagetea } \\
\hline Sanicula europaea & $\mathrm{c}$ & alk & $\mathrm{V}^{+-3}$ & . \\
\hline Actea spicata & $\mathrm{c}$ & neut & $\mathrm{V}^{+-1}$ & . \\
\hline Viola reichenbachiana & $\mathrm{c}$ & neut & $\mathrm{IV}^{+-1}$ & . \\
\hline Anemone nemorosa & $\mathrm{c}$ & neut & $\mathrm{III}^{+-1}$ & $\mathrm{II}^{+}$ \\
\hline Hepatica nobilis & $\mathrm{c}$ & alk & II $^{1}$ & . \\
\hline Poa nemoralis & $\mathrm{c}$ & alk & $\mathrm{III}^{+}$ & . \\
\hline Epipactis helleborine & $\mathrm{c}$ & alk & $\mathrm{II}^{+}$ & . \\
\hline \multicolumn{5}{|l|}{ ChCl. Vaccinio-Piceetea } \\
\hline Vaccinium myrtillus & $\mathrm{c}$ & acid $^{-}$ & $\mathrm{IV}^{+-5}$ & $\mathrm{III}^{2-4}$ \\
\hline Vaccinium vitis-idaea & $\mathrm{c}$ & acid & $\mathrm{II}^{+}$ & $\mathrm{II}^{2}$ \\
\hline Orthilia secunda & $\mathrm{c}$ & acid $^{-}$ & $\mathrm{II}^{+}$ & . \\
\hline Dryopteris dilatata & $\mathrm{c}$ & acid $^{-}$ & $\mathrm{II}^{+}$ & . \\
\hline Trientalis europaea & $\mathrm{c}$ & acid & $\mathrm{III}^{+}$ & . \\
\hline Pleurozium schreberi & d & - & $\mathrm{II}^{+}$ & $\mathrm{II}^{+}$ \\
\hline \multicolumn{5}{|l|}{ Others: } \\
\hline Oxalis acetosella & $\mathrm{c}$ & neut & $\mathrm{IV}^{+-2}$ & $\mathrm{IV}^{+-2}$ \\
\hline Majanthemum bifolium & $\mathrm{c}$ & acid $^{-}$ & $\mathrm{V}^{+-2}$ & III $^{1}$ \\
\hline Ajuga reptans & $\mathrm{c}$ & neut & $\mathrm{IV}^{+-2}$ & . \\
\hline Mycelis muralis & $\mathrm{c}$ & neut & $\mathrm{IV}^{+-1}$ & II $^{1}$ \\
\hline Luzula pilosa & $\mathrm{c}$ & neut & $\mathrm{V}^{+-1}$ & . \\
\hline Fragaria vesca & $\mathrm{c}$ & neut & III I-2 $^{1-2}$ & . \\
\hline Pteridium aquilinum & $\mathrm{c}$ & acid & . & $\mathrm{II}^{3}$ \\
\hline Athyrium filix-femina & $\mathrm{c}$ & acid $^{-}$ & II $^{1}$ & . \\
\hline Hieracium murorum & $\mathrm{c}$ & neut & $\mathrm{III}^{+-1}$ & . \\
\hline Lysimachia nummularia & $\mathrm{c}$ & neut & $\mathrm{II}^{2}$ & . \\
\hline Viola riviniana & $\mathrm{c}$ & alk & $\mathrm{II}^{2}$ & . \\
\hline Hieracium lachenali & $\mathrm{c}$ & acid $^{-}$ & $\mathrm{II}^{1}$ & . \\
\hline Deschampsia caespitosa & $\mathrm{c}$ & neut & II $^{1}$ & . \\
\hline Genista tinctoria & $\mathrm{c}$ & neut & II $^{1}$ & . \\
\hline Moehringia trinervia & $\mathrm{c}$ & alk & $\mathrm{II}^{+}$ & . \\
\hline Veronica chamaedrys & $\mathrm{c}$ & neut & $\mathrm{II}^{+}$ & . \\
\hline Agrostis capillaris & $\mathrm{c}$ & neut & $\mathrm{II}^{+}$ & . \\
\hline Vicia sepium & $\mathrm{c}$ & alk & $\mathrm{II}^{+}$ & . \\
\hline Veronica officinalis & $\mathrm{c}$ & acid $^{-}$ & $\mathrm{II}^{+}$ & . \\
\hline Hypericum maculatum & $\mathrm{c}$ & neut & $\mathrm{II}^{+}$ & . \\
\hline Geranium robertianum & $\mathrm{c}$ & neut & $\mathrm{II}^{+}$ & . \\
\hline
\end{tabular}


Table 3. Continued.

\begin{tabular}{|c|c|c|c|c|}
\hline Epilobium montanum & c & neut & $\mathrm{II}^{+}$ &. \\
Calamagrostis epigejos & c & acid- & $\mathrm{II}^{+}$ & $\mathrm{II}^{+}$ \\
Knautia arvensis & $\mathrm{c}$ & alk & $\mathrm{II}^{+}$ & $\cdot$ \\
Pimpinella saxifraga & $\mathrm{c}$ & $\mathrm{alk}$ & $\cdot$ & $\mathrm{II}^{+}$ \\
Carex pallescens & $\mathrm{c}$ & acid & $\mathrm{II}^{+}$ & $\cdot$ \\
Poa pratensis & $\mathrm{c}$ & neut & &. \\
\hline
\end{tabular}

area, compared to the untransformed area (1 species) $(P=0.02, U=2.34)$. A similar situation was found for neutrophytes which favour neutral soils -25 neutrophytes were found on the gob piles, and 8 in the untransformed areas $(P=0.01, U=2.42)$. These clear differences in the number of species favouring richer habitats correlate with the substrate properties (Table 4). The number of alkaline species positively correlates with the substrate $\mathrm{pH}\left(r_{s}=0.79, P=0.02, t=3.21\right)$, the total of exchangeable alkalis $\left(r_{s}=0.87, \mathrm{P}=0.005\right.$, $t=4.27)$ and $\mathrm{Ca}, \mathrm{K}, \mathrm{Na}$ and $\mathrm{Mg}$ content. But the strongest correlations were found with the $\mathrm{Ca}$ and $\mathrm{K}$ contents $\left(r_{s}=0.92, P=0.001, t=5.58\right)$. A similar correlation was found for the analysis of the neutrophytes. However, for the species preferring acidic and very acidic substrates, the correlations were not statistically significant (Table 4).

When analysing the percentage of species in both habitat groups (gob piles and untransformed areas) in terms of syntaxa, it was found that species of mesophilous deciduous forests, characteristic of the Querco-Fagetea class (13 species), formed a significant percentage in the gob pile communities (both qualitatively and quantitatively). In contrast, there were only 4 species found in the untransformed areas (Table 3). The difference in the percentage of these species is significant $(P=0.02, U=2.34)$. The percentage of species characteristic of the QuercoFagetea class positively correlates with the substrate $\mathrm{pH}$ $\left(r_{s}=0.81, P=0.01, t=3.35\right)$; the total of exchangeable alkalis $\left(r_{s}=0.83, P=0.01, t=3.66\right)$, and $\mathrm{Ca}, \mathrm{K}, \mathrm{Na}$ and $\mathrm{Mg}$ content. The strongest correlation $\left(r_{s}=0.93\right.$, $P=0.0009 ; t=6.09$ ) was found between the number of these species and the Na content (Table 4). However, the differences in the percentage of species characteristic of Vaccinio-Piceetea between the two types of habitats are not statistically significant $(P>0.05)$. Here, 9 species were recorded on the gob piles and 6 species in the untransformed areas (Table 3).

Correlations between the chemical properties of the substrate and the increase in species richness occur in many different areas [52-56]. In those researched for the present paper, the main factors influencing the increase in the number of species are the specific chemical and physical properties of the material previously mined and left piled around the shaft heads. The increase in species richness is correlated with the properties of the substrate such as $\mathrm{pH}$, the total exchangeable alkalis and $\mathrm{Ca}, \mathrm{K}, \mathrm{Na}$, and $\mathrm{Mg}$ contents (Table 4).

The $\mathrm{pH}$ range of a given habitat can also affect its species richness. Schuster and Diekmann [57] stated that a $\mathrm{pH}$ of about 5.0 to about 6.0 is the most favourable for species diversity, because both acidophytes and alkaline species can coexist on this type of substrate. Only in the case of lower or much higher $\mathrm{pH}$ will the number of species in a given habitat decrease (either only acidophytes or only alkaline species), due to the limited ecological tolerance of plants. This phenomenon was confirmed in the areas currently researched, which showed the $\mathrm{pH}$ range of the gob piles as being very favourable, ranging from 5.3 to 7.0 (Table 1). This allows for the occurrence of both acidophytes and alkaline species (Table 3), and influences the increase in the total number of species of the former mining areas [34].

It is also interesting that in the researched areas the increase in species richness does not result from the domination of random species (e.g., anthropophytes), as frequently seen in post-mining areas [58-60], but from an increased percentage of native species (mainly forest species - Table 3). This is an extremely rare phenomenon in post-mining areas and can be explained by two factors: the nature of the overburden (the unprocessed material resembling natural substrate); and age [36], as heaps are sometimes older than 200 years and already demonstrate very advanced succession. These species form specific forest phytocoenosis of a mesophilic deciduous character, in contrast to untransformed areas surrounding the heaps where acidophilic communities occur $[33,35]$.

A similar influence of anthropogenic transformation on soil properties and vegetation has been described by, for example, Janqueira et al. [61] for the Amazon area. On anthropogenic soils formed as a result of human activity in the Amazon Rainforest, forest communities with different floral compositions have developed from the primary communities of the area, growing on untransformed soil. This phenomenon is caused by the increased $\mathrm{pH}$ values of the secondary soils, which generate a different direction of succession 
Table 4. Spearman's rank correlation coefficients $\left(r_{\mathrm{s}}\right)$ for some chemical characteristics of soils (units are contained in Tables 1 and 2 ) and distinguished groups of species found in the gob piles and in their surroundings in the northern foreland of the Świętokrzyskie Mountains (SE Poland); Q-F - Querco-Fagetea class, V-P - Vaccinio-Piceetea class; others abbreviations - see Table 3. ${ }^{*} 0.05 \geq \mathrm{P} \geq 0.01$; ${ }^{* *} 0.01>\mathrm{P} \geq 0.001 ;{ }^{* * *} 0.001>\mathrm{P} \geq 0.0001$.

\begin{tabular}{|c|c|c|c|c|c|c|c|c|}
\hline Variables & Total number of species & alk & neut & acid- & acid & acid + & Q-F & V-P \\
\hline $\mathrm{pH}$ & $0.78^{*}$ & $0.79^{*}$ & $0.80^{*}$ & 0.58 & -0.01 & 0.11 & $0.81^{*}$ & 0.23 \\
\hline Total exchangeable alkalis & $0.84^{* *}$ & $0.87^{* *}$ & $0.85^{* *}$ & $0.71^{*}$ & -0.06 & 0.33 & $0.83^{*}$ & 0.23 \\
\hline Exchangeable acidity & -0.37 & -0.36 & -0.35 & -0.30 & 0.38 & -0.65 & -0.49 & -0.03 \\
\hline Hydrolytic acidity & -0.68 & $-0.72 *$ & $-0.80^{*}$ & -0.47 & 0.35 & -0.22 & $-0.77 *$ & 0.01 \\
\hline Ca content & $0.89^{* *}$ & $0.92 * *$ & $0.90^{* *}$ & $0.80^{*}$ & 0.00 & 0.44 & $0.83^{*}$ & 0.33 \\
\hline K content & $0.89^{*}$ & $0.92^{* *}$ & $0.90^{* *}$ & $0.80^{*}$ & 0.00 & 0.44 & $0.83^{*}$ & 0.33 \\
\hline Na content & $0.79 *$ & $0.82^{*}$ & $0.90^{* *}$ & 0.61 & -0.36 & 0.44 & $0.93^{* * *}$ & 0.05 \\
\hline Mg content & $0.83^{*}$ & $0.82^{*}$ & $0.80^{*}$ & $0.76^{*}$ & -0.06 & 0.65 & $0.75^{*}$ & 0.36 \\
\hline
\end{tabular}

and increase the floral richness of the Amazonian Rainforest. Janquiera et al. [61] emphasize that the floral composition is different in both types of forests, developing on various types of soils (anthropogenic and primary), even if they are adjacent to each other. A similar situation is observable in former areas of iron ore mining (Tables 1 and 3).

\section{Conclusions}

1) As a result of the former iron ore mining material originating from deeper rock layers was extracted to the surface (now overburden). This material has favourable physico-chemical properties, differing from the properties of the poorer soils of the untransformed areas.

2) Preferred chemical properties of the overburden, including increased $\mathrm{pH}$ values, increased content of assimilated elements ( $\mathrm{Ca}, \mathrm{Mg}, \mathrm{K}, \mathrm{Na}$ ) also affect the increase in the quality of fossil soil horizons.

3) The mining of iron ore in the past has led to significant, positive changes in the soil cover of the researched areas.

4) The clayey-silty gob piles made of overburden there have become fertile habitat islands among oligotrophic, sandy, untransformed soils, and the effect of these changes is an increase in the number of plant species.

\section{Acknowledgements}

This work was supported by the Polish National Science Centre (NCN), grant number NN 305389438.

\section{Conflict of Interest}

The authors declare no conflict of interest.

\section{References}

1. WOLTERS V. Biodiversity of soil animals and its function. Eur. J. Soil Biol. 37, 221, 2001.

2. DECAËNS T., JIMÉNEZ J.J., GIOIA C., MEASEY G.J., LAVELLE $P$. The values of soil animals for conservation biology. Eur. J. Soil Biol. 42, 23, 2006.

3. ULRICH W., ZALEWSKI M., UVAROV A.V. Spatial distribution and species co-occurrence in soil invertebrate and plant communities on northern taiga islands. Ann. Zool. Fennici 49, 161, 2012.

4. RODRIGUES P.M.S., GONÇALVES C.E., SCHAEFER R., SILVA J.O., FERREIRA JÚNIOR W.G., SANTOS R. M., NERI A.V. The influence of soil on vegetation structure and plant diversity in different tropical savannic and forest habitats. J. Plant Ecol. 11 (2), 226, 2018.

5. LOZBENEV N., SMIRNOVA M., BOCHARNIKOV M., KOZLOV D. Digital Mapping of Habitat for Plant Communities Based on Soil Functions: A Case Study in the Virgin Forest-Steppe of Russia. Soil Syst. 3 (19), 1, 2019.

6. THIES, J.E., GROSSMAN J.M. The soil habitat and soil ecology. In Biological Approaches to Sustainable Soli Systems; N. Uphoff, A. S.Ball, E. Fernandes, H. Herren, O. Husson, M. Laing, C. Palm, J. Pretty, P. A. Sanchez, N. Sanginga and J. E.Thies, Eeds. CRC Press, Boca Raton, FL, pp. 59, 2006.

7. PASAYAT M., PATEL A.K. Assessment of PhysicoChemical Properties Influencing Mine Spoil Genesis in Chronosequence Iron Mine Overburden Spoil and Implications of Soil Quality. Int. J. Curr. Microbiol. App. Sci 4 (6), 1095, 2015.

8. VOLUNGEVIČIUS J., SKORUPSKAS R. Classification of anthropogenic soil transformation. Geologija 53, 4 (76), 165, 2011.

9. DAZZI C., LO PAPA G. Anthropogenic soils: general aspects and features. Ecocycles 1 (1), 3, 2015.

10. LIN B.B., CHAPPELL M.J., VANDERMEER J., SMITH G., QUINTERO E., KERR R.B., GRIFFITH D.M., KETCHAM S.R., LATTA S.C., MCMICHAEL P., MCGUIRE K.L., NIGH R., ROCHELEAU D., SOLURI J., PERFECTO I. Effects of industrial agriculture on climate change and the mitigation potential of smallscale agroecological farms. Perspec. Agricul. Vet. Science Nutrition Natural Res. 6 (20), 1, 2011. 
11. HAYTER R. Industrialization. In Barney Warf. Ed. Oxford Bibliographies in Geography; New York, Oxford University Press, 1, 2013.

12. NANG B.D. Impacts of anthropogenic activities on physical and selected chemical properties of soils in the natural forest-savanna of Northern Ghana. J. Soil Science Environ. Manag. 7 (5), 53, 2016.

13. SANDOR J.A., HOMBURG J.A. Anthropogenic soil change in ancient and traditional agricultural fields in arid to semiarid regions of the Americas. J. Ethnobiol. 37 (2), 196, 2017.

14. GHOSE M.K. Effect of opencast mining on soil fertility. J. Scient. Industrial Research 63, 1006, 2004.

15. KUMAR J., KUMAR A. Chemical Characterization and Mine Soil Genesis in Age Series Coal Mine Overburden Spoil in Chronosequence in a Dry Tropical Environment. J. Phylogen. Evolution. Biol. 1, 101, 2013.

16. KULCZYCKA J., PIETRZYK-SOKULSKA E., UBERMAN R. The impact of mining on the environment in Poland - myths and reality. Mineral Resour. Manag. 31, (1), 45, 2015.

17. THOMAS C., SEXSTONE A., SKOUSEN J. Soil biochemical properties in brown and gray mine soils with and without hydroseeding. Soil 1, 621, 2015.

18. TAMBUNAN R.P., SYEKHFANI S., PRIATMADI B.J. The role of ground cover plant in soil improvement after mining activity in South Kalimantan. IOSR J. Agricul. Vet. Science 10 (11), 92, 2017.

19. MUKHOPADHYAY S., MAITI S.K. Mine spoil reclamation due to tree plantation: a chronosequence study. African J. Basic Appl. Science 3, 210, 2011.

20. OGGERI C., FENOGLIO T.M., GODIO A., VINAI R. Overburden management in open pits: options and limits in large limestone quarries. Int. J. Mining Science Tech. 29, 217, 2019.

21. LEMKE D., SCHWEITZER C.J., I.A. TAZISONG I.A., WANG Y. AND BROWN J.A. Invasion of a mined landscape: what habitat characteristics are influencing the occurrence of invasive plants? Int. J. Mining, Reclamation. Environ. 1, 1, 2012.

22. KABRNA M., HENDRYCHOVÁ M., PRACH K. Establishment of target and invasive plant species on a reclaimed coal mining dump in relation to their occurrence in the surroundings. Int. J. Mining, Reclamation Environ. http://dx.doi.org/10.1080/17480930.2013.820390, 2014.

23. EZEAKU P.I., DAVIDSON A. Analytical situations of land degradation and sustainable management strategies in Africa. J. Agricultural Soc. Science 4, 42, 2008.

24. MAHALIK G., SATAPATHY K.B. Environmental impacts of mining on biodiversity of Angul - Talcher open mining site, Odisha, India. Sch. Acad. J. Biosci. 4 (3A), 224, 2016.

25. GIAM X., OLDEN J.D., SIMBERLOFF D. Impact of coal mining on stream biodiversity in the US and its regulatory implications. Nature Sustainability 176 (1), 176, 2018.

26. SONTER L.J., ALI S.H., WATSON J.E.M. Mining and biodiversity: key issues and research needs in conservation science. Proc. R. Soc. B 285, 20181926, 2018.

27. GULDON Z. Old Polish Industrial District. In Old Polish Industrial District; P. Pierściński, Ed., Sam-Wil, Kielce, 32, 2001.

28. PODGÓRSKA M. Proposed documentary station in the vicinity of Sowia Góra in the Gielniowski Hummock (Małopolska Upland). Prob. Ekol. Kraj. 29, 199, 2011a [In Polish]
29. GRIFFITH J.J., TOY T.J. Evolution in revegetation of iron-ore mines in Minas Gerais State, Brazil. Unasylva 207 (52), 9, 2001.

30. ŘEHOUNKOVÁ K., PRACH K. Spontaneous vegetation succession in disused gravel-sand pits: Role of local site and landscape factors. J. Veg. Science 17, 583, 2006.

31. BZDON G. Gravel pits as habitat islands: floristic diversity and vegetation analysis. Pol. J. Ecol. 56 (2), 239, 2008.

32. GOSWAMI S. Impact of Coal Mining on Environment. European Researcher 92 (3), 185, 2015.

33. PODGÓRSKA M. The impact of former iron ore mining on the transformation of vegetation cover of the Gielniowski Hump (Małopolska Upland). Biodiv. Res. Conserv. 17, 53, 2010.

34. PODGÓRSKA M. Specific remnants of old iron-ore extraction sites as islands of plant species richness. Open Life Sci. 10, 182, 2015.

35. PODGÓRSKA M. The long-term changes of forest communities as an effect of former iron-ore mining activities and current forest management: importance for local biodiversity. - Pol. J. Ecol. 64, 35, 2016.

36. PODGÓRSKA M. Former iron mining sites as habitat islands for ancient woodland plant species. Pol. J. Ecol. 66, 227, 2018.

37. KLECZKOWSKI A. Iron ores in the Bunter deposits of the northern margins of the Góry Świętokrzyskie. Prac. Muz. Ziemi 15 (1), 193, 1970 [In Polish].

38. PODGÓRSKA M. Vascular plants flora of the Gielniowski Hummock (Małopolska Upland). Botanical Papers 44, 304, 2011b [In Polish].

39. KRAJEWSKI R. Clay iron ores in the eastern part of the District Końskie. Biuletyn, 26, 135, 1947 [In Polish].

40. BRAUN-BLANQUET J. Pflanzensoziologie, Grundzüge der Vegetationskunde. 3. Aufl.; Springer, Wien-New York, 865, 1964.

41. ZARZYCKI K., TRZCIŃSKA-TACIK H., RÓŻAŃSKI W., SZELĄG Z., WOŁEK J., KORZENIAK U. Ecological indicator values of vascular plants of Poland. In Biodiversity of Poland 2; Z. Mirek Ed.; W. Szafer Institute of Botany, Polish Academy of Sciences, Kraków, pp. 183, 2002.

42. KOWALKOWSKI A., CZĘPIŃSKA-KAMIŃSKA D., KRZYŻANOWSKI A., OKOŁOWICZ M., CHOJNICKI J. Klasyfikacja gleb leśnych Polski. CILP, Inowrocław, pp. 123, 2000 [In Polish].

43. MIREK Z., PIĘKOŚ-MIRKOWA H., ZAJĄC A., ZAJĄC M. Flowering plants and pteridophytes of Poland a checklist. In Biodiversity of Poland 1; Z. Mirek Ed.; W. Szafer Institute of Botany, Polish Academy of Sciences, Kraków, 442, 2002.

44. MATUSZKIEWICZ W. Plant Communities in Poland Marking Guide, Wydawnictwo Naukowe PWN, Warszawa, 537, 2014 [In Polish].

45. STATSOFT. STATISTICA (data analysis software system), version 6.1. StatSoft, Inc., Tulsa, OK, 2003.

46. SWAŁDEK M. Transformation of soil cover and plant communities in the Old-Polish Industrial District; Polish Academy of Sciences, Warszawa, 93, 1983 [In Polish].

47. ADAMCZYK B. Studies on the development of relations between parent rock and soil. Part I: Soils of the forest reserve 'Świnia Góra' formed on rocks of the Variegated (New Red) Sandstone age (Lower Triassic). Acta Agr. Silv. 5, 3, 1965 [In Polish].

48. PRESLEY D.R., HARTLEY P.E., RANSOM M.D. Mineralogy and morphological properties of buried polygenetic paleosols formed in late quaternary sediments 
on upland landscapes of the central plains, USA. Geoderma 154, 508, 2010.

49. MOHANTY S.P., NANDA S. Geochemistry of a paleosol horizon at the base of the Sausar Group, central India: Implications on atmospheric conditions at the Archeane Paleoproterozoic boundary. Geoscience Frontiers 7, 759, 2016.

50. YASEEN S., PAL A., SINGH S., DAR I.Y. A Study of Physico-Chemical Characteristics of Overburden Dump Materials from Selected Coal Mining Areas of Raniganj Coal Fields, Jharkhand, India. Global J. Science Frontier Res. Enviorn. Earth Sciences 12 (1), 660103, 2012.

51. TRAJKOVIĆ I., LIČINAA V., ANTIĆ-MLADENOVIĆ S., WENZEL W. Hazardous elements speciation in sandy, alkaline coal mine overburden by using different sequential extraction procedures. Chemical Spec. Bioavailability 26 (2), 85, 2014

52. LAMB E.G., KENNEDY N., SICILIANO S.D. Effects of plant species richness and evenness on soil microbial community diversity and function. Plant Soil 338, 483, 2011.

53. POHL M., GRAF F., BUTTLER A., RIXEN CH. The relationship between plant species richness and soil aggregate stability can depend on disturbance. Plant Soil 355, 87, 2012.

54. WHISLER K.M., ROWE H.I., DUKES J.S.. Relationships among land use, soil texture, species richness, and soil carbon in Midwestern tallgrass prairie, CRP and crop lands. Agriculture Ecosystems Environ. 216, 237, 2016
55. EL MOUJAHID L., LE ROUX X., MICHALET S., BELLVERT F., WEIGELT A., POLY F. Effect of plant diversity on the diversity of soil organic compounds. PLoS ONE 12 (2), e0170494. 2017.

56. TILK M., TULLUS T., OTS K. Effects of environmental factors on the species richness, composition and community horizontal structure of vascular plants in Scots pine forests on fixed sand dunes. Silva Fennica 51 (3), 6986.18, 2017.

57. SCHUSTER B. \& DIEKMANN M. Changes in species density along the soil $\mathrm{pH}$ gradient - evidence from German plant communities. Folia Geobotanica 38 (4), 367, 2003.

58. ROSS K.A., FOX B.J., FOX M.D. Changes to plant species richness in forest fragments: fragment age, disturbance and fire history may be as important as area. J. Biogeogr. 29, 749, 2002

59. HOWORTH R.T., PENDRY C.A. Post-cultivation secondary succession in a Venezuelan lower montane rain forest. Biodiv. Conserv. 15, 693, 2006.

60. CALINGER K., CALHOON E., CHANG H., JAMES WHITACRE J., WENZEL J., LIZA COMITA L., SIMON QUEENBOROUGH S. Historic Mining and Agriculture as Indicators of Occurrence and Abundance of Widespread Invasive Plant Species. PLoS ONE 10 (6), e0128161, 2015.

61. JUNQUEIRA A.B., SHEPARD H.JR., CLEMENT CH.R. Secondary forests on anthropogenic soils in Brazilian Amazonia conserve agrobiodiversity. Biodiv. Conserv. 19, 1933, 2010. 